\title{
Stress Management in the Modern Workplace and the Role of Human Resource Professionals
}

http://doi.org/10.21272/bel.4(2).26-40.2020

\author{
Cam T.H. Tran, ORCID: https://orcid.org/0000-0001-8213-0025
}

Graduate Researcher, MBA Scholar, Faculty of Business Administration, International School of Business University of Economics, HCMC, Vietnam

Hieu T.M. Tran, ORCID: https://orcid.org/0000-0002-6286-2090

Graduate Researcher, MBA Scholar, Faculty of Business Administration, International School of Business University of Economics, HCMC, Vietnam

Huy T.N. Nguyen, ORCID: https://orcid.org/0000-0002-7052-2408

Graduate Researcher, MBA Scholar, Faculty of Business Administration, International School of Business University of Economics, HCMC, Vietnam

Dung N. Mach, ORCID: https://orcid.org/0000-0001-8767-9228

Graduate Researcher, MBA Scholar, Faculty of Business Administration, International School of Business University of Economics, HCMC, Vietnam

Hung S.P. Phan, ORCID: https://orcid.org/0000-0001-6547-0191

Graduate Researcher, MBA Scholar, Faculty of Business Administration, International School of Business University of Economics, HCMC, Vietnam

Bahaudin G. Mujtaba, D.B.A., ORCID: https://orcid.org/0000-0003-1615-3100

Professor, Huizenga College of Business and Entrepreneurship, Nova Southeastern University, Fort Lauderdale, Florida, USA

\section{Abstract}

Due to the potentially negative impact on the employees' well-being and productivity, the stress in the workplace becomes one of the most difficult problems for the enterprise's successful operation. The frequency of its manifestations in the workplace is constantly increasing. These issues are especially relevant in the Covid-19 era, when HR managers constantly have to form and implement policies to protect the employees' mental health and general working conditions. It creates the preconditions to identify the factors underlying the occurrence of stress and employees' potential behavioral responses. The aim of this study is to analyze and evaluate certain aspects of stress in the workplace. Based on the systematization of the results from previous research and interviews with five experienced heads and managers of Vietnamese companies, the article identifies and classifies common reasons, signs, symptoms and consequences of workers' stress. The classification of stress in the workplace into three categories (acute stress, episodic acute and chronic stress) forms the basis for identifying the source of stress as a result of the manifestation of factors which differ from the usual ones for the worker, taking into account their external and internal peculiarities. The article proposes an approach based on a combination of psychological, physiological and autonomic methods to measure stress. It takes into account its cognitive, physical, emotional and behavioral symptoms to increase the accuracy for evaluating the practical application of stress minimization strategy. The paper examines the relationship between individual, organizational and financial effects of stress. It identifies four problems faced by staff in the workplace: identifying the reasons of stress, identifying ways to minimize it, resolving conflict, and developing proposals and recommendations for reducing stress. According to the analysis of five interviews with experienced managers from Vietnamese companies, there are recommendations on how to form and implement stress management strategies for human resource managers. Primary, secondary and tertiary approaches to workplace stress reduction are proposed based on managers' individual and organizational interventions focused on different goals. Thus, human resource managers play an essential role in the development of stress management strategies to facilitate the interactive internal exchange of information and to establish a balanced personnel structure of the organization.

Keywords: Eustress, Distress, Stress, Stress Management, Workplace.

JEL Classification: D73, L51, M31, I32. 

and Leadership, 4(2), 26-40. http://doi.org/10.21272/bel.4(2).26-40.2020.

(C) The Authors, 2020. This article is published with open access at Sumy State University.

\section{Introduction}

Stress is the non-specific response of the body to persistent and uncertain demands for change (Selye, 1936). Some stress can be positive as it can motivate employees to focus on a task or to act and solve a problem (Canadian Mental Health Association, 2016). But if stress occurs too often by going beyond an optimal level or lasts too long, it may cause negative effects such as strain and burnout (see Figure 1).

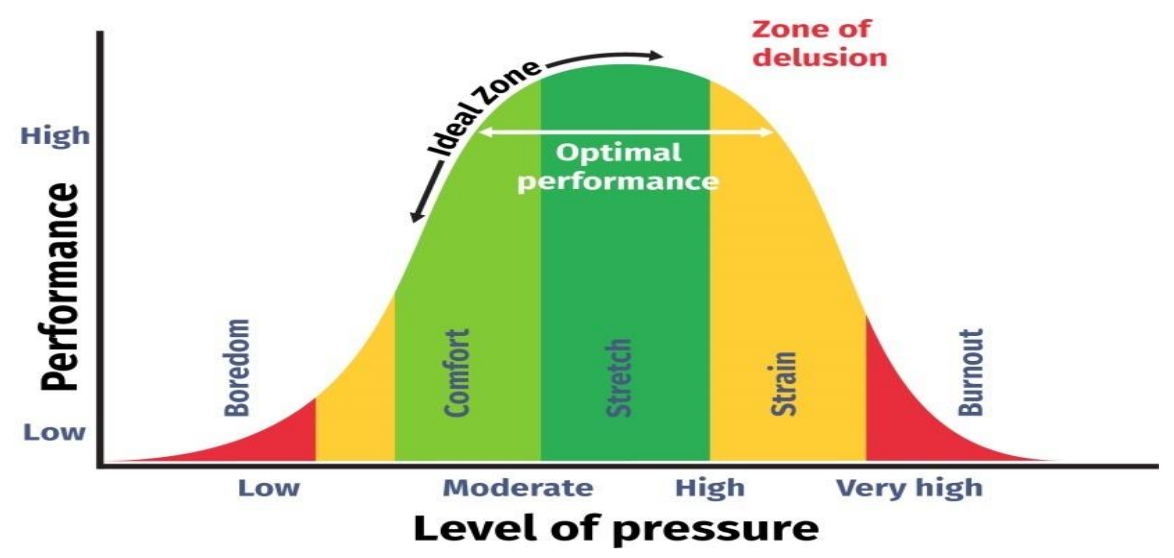

Figure 1. Stage of the stress response

Source: Martin, 2018

Stress at the workplace is the adverse reactions of physical and mental forms that could occur when there is a conflict between job needs and the degree of control that staff is given to meet these requirements (Canadian Mental Health Association, 2016). Workplace stress has been demonstrated to have a harmful influence on the health and well-being of workers, as well as negative effects on productivity and profits (Bickford, 2005). For this reason as well as workplace mobbing, bullying, the transnational competition to streamline operations, and the outbreak of Coronavirus all over the world, stress at the workplace is a cosmopolitan or multicultural issue which is becoming a big concern in the current state of the economy (Ibrahim, Imtiaz, Mujtaba, Vo, \& Ahmed, 2020; Mujtaba, Cavico, and Senathip, 2020; Ahmed, Khan, Khan, \& Mujtaba, 2020).

Although many higher education institutions, firms, cities, states, and nations are doing a great job of testing, tracing and treating (TTT) those impacted by the Coronavirus (Covid-19), many students, faculty, staff, employees, and other professionals all around the globe are going to continue experiencing some level of anxiety and stress as they begin to return to work or continue performing their responsibilities. As such, the modern employees all across the globe are likely to experience some forms of stress in their day-to-day jobs, and Vietnamese workers are just as likely to be victims of stress as any other global citizen (Mujtaba, \& Awan, 2019; Nguyen, Lee, Mujtaba, and Ruijs, 2013; Nguyen, Mujtaba, \& Pham, 2013; Shoaib, Mujtaba \& Awan, 2019). In this study, without limiting our focus to any specific nation, we look at the role of human resource professionals and how they can effectively help employees manage their workplace stress levels.

The human resources (HR) department handles many necessary functions of the business, including improving occupational safety and health of employees. Hence, HR managers are not only responsible for making sure that managers are not stressing out their employees and recognizing signs of stress amongst their staff to take actions but also the need to understand the importance of stress prevention. This paper will discuss some of the relevant 
and practical literature as well as the causes, the effects, and the role of human resource managers in managing stress.

\section{Literature review}

Stress is an ordinary response of the body when changes happen. The physical, mental and emotional reactions will be used by the body in response to change. The environment, the body and thoughts are all factors that influence stress (Cleveland Clinic, 2015). Workplace stress is the reaction that individuals have when some types of work demands do not suit their capacities and knowledge, or when work pressures exceed one's ability to handle it effectively (Semmer, 2007). Stress is the physiological reaction of a person to an external stimulus that causes the "fight-or-flight" response (Mujtaba and McCartney, 2010; Stress Management, 2020). According to the American Psychological Association (APA), stress is classified into three categories of acute, episodic and chronic.

Acute stress: Acute stress is the most common type. It happens in the short-term and does not always have a negative meaning, because the current tensions help to train and stimulate one's brain's development to deal with stressful situations in the future. Acute stress often proceeds from reactive thinking for events that have recently happened, or upcoming challenges and needs.

Episodic acute stress: Episodic acute stress happens when people frequently suffer stress or people who face frequent triggers of stress and have a crisis in their current life. Episodic acute stress is often found in people who feel the pressure of overload, take on too much responsibility, and make unrealistic demands and unreasonable goals that exceed their ability to perform it on time.

Chronic stress: Chronic stress is considered the most harmful type of stress, and it is the opposite of acute stress. It happens when people have serious and long-term problems such as their life being out of control and give up looking for solutions. Chronic stress is the most dangerous. It can cause adverse effects on both physical health and mental health (Felman, 2017).

\section{Empirical papers}

Manoj (2013) researched the employee stress and showed that the workplace of many organizations has become an environment with high-stress rates. High workload, tight deadlines, stretch or unrealistic targets, lack of job satisfaction, long working hours, the pressure to perform, and interpersonal conflicts are some of the main factors leading to tension among employees. Stress influences productivity, morale and the motivation of workers, and the profitability of organizations. Moreover, it causes health problems such as insomnia, depression, and heart disease (Manoj, 2013). Hans Selye (1936), who is known as the "father of stress research", described stress as the "nonspecific response of the body to any demand." In his early work on the topic of stress, Selye (1936) conceptualized two categories, namely good or desirable stress (eustress) and bad or undesirable stress (distress).

Workplace stress is becoming the top concern of many organizations in the growing economic situation, in which conditions of overwork, job insecurity, low levels of job satisfaction, and lack of autonomy in organizations across the globe are the causes of it at work (Mujtaba, Cavico, and Senathip, 2020; Ibrahim, Imtiaz, Mujtaba, Vo, \& Ahmed, 2020). Workplace stress has been demonstrated to cause a negative influence on the health of staff and the revenue of organizations. Also, recognizing the symptoms of stress and being aware of the impacts of stress on employee's health as well as company's profits are the top priorities to help employees overcome tension (Bickford, 2005).

These days, stress is defined in terms of its physical and physiological effects on a person and can be a mental, physical, or emotional strain. Stress occurs due to a demand that exceeds the individual's coping ability, disrupting his or her psychological equilibrium (Ahmad, Hussain, Saleem \& Qureshi, 2015: 46). Occupational ill health, low productivity and human mistakes are principal reasons related to job stress. It raises the illness of the body, including heart disease, back pain, headaches, and gastrointestinal disturbances, as well as an increase in staff turnover and accidents because of human errors. Besides that, stress also impacts people psychologically through anxiety and depression and reduces one's ability to concentrate, work performance and effective decision making (Kazmi, 2019). Stress is one of the biggest problems that most employees are facing. It is also the major concern of employers. Stress can have positive or negative effects on everyone's life, and it can cause harm to both individuals and organizations. 
For this reason, Greeshma, Priya, Aswathy, and Janani (2018) advised that human resource managers should communicate with employees who are stressed to find out the reasons and then share the solutions with them. Furthermore, the company should organize regular and periodic stress relief programs for workers and design a reasonable working schedule to give employees enough rest (Greeshma et al., 2018).

In the workplace environment, Lazarus (1991) postulated that stress is a process, involving a transaction between an individual and his or her work environment. Besides, stress is usually categorized as being either acute, posttraumatic, or chronic (Kendall et al., 2000). People who experience an acute stress response usually return to "normal" life within a short period (Kendall et al., 2000). Unlike acute stress or post-traumatic stress, when individuals have been continually exposed to stress for long periods (i.e. their stress responses are continuously activated) chronic stress can occur (Bickford, 2005).

Stress affects not only the leadership but also everybody else working in the organization; therefore, due attention should be given for its elimination (Seňová \& Antošová, 2014). As managers, it is imperative to strive for a better understanding of the process of workplace stress (Tucker et al., 2013) to comprehend the causes of workplace stress, effects of workplace stress, and interventions to manage it (Ahmad et al., 2015). Many research studies have shown strong relationships between the experience of chronic stress and the development of illness and disease (Grimshaw, 1999). Vanishree (2014) performed research to analyze the stressors of employees in small and medium-sized businesses and concluded that work overload, work ambiguity, and workplace conflict are major sources leading to stress among employees. From the research results, the author recommended that the organization should apply relevant techniques to redesign the work while organizing many consultations and workshops to support employees in reducing their levels of stress.

\section{Methodology}

In this paper, we use a qualitative methodology to analyze workplace stresses. Firstly, we carefully review the literature of previous research papers on this issue. After that, we conducted qualitative interviews with five experienced current leaders and managers at Vietnamese companies on their observations about workplace stresses in each working environment in recent years. Each interview was based on the manager's voluntary consent. It took about one hour of their time starting with structured questions but leading to open-ended discussions (unstructured) based on the responder's answers. The written responses were verified with the managers within one week of the initial interview. The findings of these qualitative unstructured interviews are presented in the following sections and tables while being supported with published literature from recognized authorities.

\section{Analysis}

\section{Sources of workplace stress}

As emphasized by the Vietnamese leaders and managers during the qualitative interviews, stress can be the result of any situation in the workplace, including but not limited to the person, the task, the organization, the work environment, management style, personality, and other variables or uncertainties surrounding a specific task or situation. Stress is one of the phenomena frequently occurring with employees who face uncertain opportunities and problems simultaneously. There might be many sources of stress - minor or major from within the organization and from the outside (Ahmad et al., 2015). Environmental factors are usually considered as the primary cause of stress. However, other views promote that individual differences of the worker such as personality, age, education, experience, and coping style are most important in predicting whether certain job specifications will result in stress (World Health Organization, 2007).

Generally, job stressors may not only come from environmental factors but also individual differences. To be more specific, Table 1 shows categories of workplace stressors and examples that were collected by Beehr and Newman (1978) and often mentioned by those interviewed for this research in Vietnam. 
Table 1. Categories of workplace stressors and examples

\begin{tabular}{|c|c|}
\hline Categories of Job Stressors & Environmental Factors - Examples \\
\hline Job demands and task characteristics & $\begin{array}{l}>\text { weekly work schedule; } \\
>\text { over and under-utilization of skills; } \\
>\text { variance in workload; } \\
>\text { the pace of work; } \\
>\text { responsibility (for people or things); } \\
>\text { travel as part of the job; } \\
>\text { job characteristics thought to be intrinsically motivating }\end{array}$ \\
\hline Role demands & $\begin{array}{l}>\text { role overload; } \\
>\text { role conflict; } \\
>\text { role ambiguity }\end{array}$ \\
\hline Organizational characteristics and conditions & $\begin{array}{l}>\text { company size; } \\
\text { job security (fear of redundancy either from the economy, or a lack of tasks or work to } \\
\text { do); } \\
\text { } \text { socio-technical changes; } \\
>\text { organizational structure (and job's position within the hierarchy); } \\
>\text { the communication system (and job's position within the system); } \\
>\text { subsystem relations; } \\
>\text { staffing policies and procedures; } \\
>\text { management style (philosophical and operational); } \\
>\text { evaluation, control, and reward systems; } \\
>\text { training programs; } \\
>\text { organizational climate; } \\
>\text { opportunity for advancement; } \\
>\text { required relocation; } \\
>\text { local union constraints }\end{array}$ \\
\hline \multirow[t]{2}{*}{ Organization's external demands and conditions } & $\begin{array}{l}>\text { number and nature of customers or clients; } \\
>\text { national or international unions; } \\
\text { governmental laws and regulations; } \\
>\text { suppliers; providers of needed services; } \\
>\text { technological and scientific developments; } \\
>\text { consumer movements; } \\
>\text { the geographic location of the organization }\end{array}$ \\
\hline & $\begin{array}{ll} & \text { Personal Factors - Examples } \\
\end{array}$ \\
\hline $\begin{array}{l}\text { Psychological condition (personality traits and } \\
\text { behavioral characteristics) }\end{array}$ & $\begin{array}{l}>\text { Type A; } \\
>\text { ego needs; } \\
\text { need for clarity/intolerance of ambiguity; } \\
>\text { introversion/extroversion; } \\
>\text { internal/externality; } \\
>\text { approval seeking; } \\
>\text { defensiveness; } \\
>\text { impatience; } \\
>\text { intrapersonal conflicts (e.g., between ego-ideal and reality); } \\
>\text { self-esteem; } \\
>\text { motives/goals/aspirations (career, life); } \\
>\text { typical anxiety level; } \\
>\text { perceptual style; } \\
>\text { values (human, religious, etc.); personal work standards; } \\
>\text { need for perfection; } \\
>\text { abilities (especially task- and coping-related) }\end{array}$ \\
\hline Physical condition & $\begin{array}{l}>\text { physical fitness/health; } \\
>\text { diet and eating habits; } \\
>\text { exercise, work, sleep, and relaxation patterns }\end{array}$ \\
\hline Life-stage characteristics & $\begin{array}{l}\text { human development stages; } \\
>\text { family stages; } \\
\text { career stages }\end{array}$ \\
\hline Demographics & $\begin{array}{l}>\text { age; } \\
>\text { education (amount and type); } \\
>\text { sex; } \\
>\text { race; } \\
>\text { socio-economic status; } \\
>\text { occupation, avocation }\end{array}$ \\
\hline
\end{tabular}

Source: Beehr and Newman, 1978

Besides, the study of Shukla and Garg (2013) showed three causes of stress, including organizational factors, individual factors, and job concerning factors. Organizational factors consist of giving strict rules and regulations 
within the organization, having a wage structure based on unfair discrimination, setting ambiguous goals, providing less promotional opportunities for employees, showing excessive control by managers, ineffective communications among colleagues, inflation, and changes in technology. The family and personal financial issues, and some personality traits such as being impatient, aggressive, rigid, and ineffective in time management are a few of the individual factors that can result in stress. Job concerning factors may cause stress, for instance, crowded working environments, unsafe and unhealthy working conditions, and lack of shared opinions among employees (Shukla \& Garg, 2013).

Michie (2002) classified the causes of stress into 5 categories. The first cause is intrinsic to the job, and it includes work overload, time pressures, and physical danger. The second is one's role in the organization. Role conflict, responsibility for people, and conflict of organizational boundaries are the factors that are included in this cause. The third cause is career development, namely over promotion, under promotion, lack of job security, and thwarted ambition. Besides, the relationship at work is the fourth cause. Poor relations with bosses, subordinates, colleagues, and difficulties in delegating responsibility are also considered as the main causes of this type of stress. The last is organizational structure and climate, such as little or no participation in important decisions, restrictions on behavior, and lack of effective consultation (Michie, 2002).

According to the Health and Safety Executive (2020), six key causes of stress depend on the demands, control, support, relationships, role, and changes. Factors that belong to demands are assigned workload, the type of work, and the environment to complete the work. Control shows how employees can express ideas and make decisions in their work. Support involves assistance, encouragement, and the supply of the best conditions and resources of the organization, line managers and colleagues. The relationship includes giving an impulse to positive partnerships in cooperation between employees, developing reasonable policies to cope with unacceptable behaviors and avoiding conflicts within the company. Role points out, whether the employees know clearly what role they have in the organization, and whether the organization makes sure that its employees have no conflict in their role. The last one includes changes; it provides information on how the organizational change process is managed and communicated by line managers in the organization (Health and Safety Executive, 2020).

One study by Semmer and colleagues (2014) demonstrated that illegitimate tasks were considered as a cause of work stress. Also, the result of Vanishree's research (2014) classified work overload, work's ambiguity and work conflict as key clusters of workplace stress that can lead to a lack of concentration on the job, mental block and the possibility of making ineffective decisions. Four main causes of stress that Quick and Quick (1984) suggested in the research were task demands, role demands, physical demands, and interpersonal demands. The study of Parasuraman and Alutto (1984) proposed contextual, role-related and personal stress as three main types of stress.

Furthermore, the sources of stress are also divided into two principal internal and external classifications. Internal causes are expressed through a person's perception and mind-set. The way that the person thinks about any incident or situation encountered can cause stress for themselves. External causes involve job insecurity, working hours, control at work, and managerial style. Moreover, shortage of employees and the imbalance of work and life activities are considered as important contributors to stress at the workplace (Panigrahi, 2017). In a survey of 1,299 employees from 37 organizations, Malik found ten factors that can cause stress for employees. These include policies that prohibit employees to freely talk with each other during working hours. The other factor is that stress comes from many personal conflicts at work which occur at the same time or between departments. Some employees are not provided with enough control over their jobs and this was mentioned by several Vietnamese respondents as some managers behave according to the socialization of high power-distance norms in most East-Asian countries. The lack of support from supervisors, open communications between managers and employees and recognition or reward when employees complete the job, coping with bureaucratic red tape, job difficulty, and low benefits about health and vacation are all causes of employee stress (Malik, 2011).

\section{Measuring Stress}

According to Panigrahi (2017), there are three methods used to measure tension: psychological, physiological, and autonomic measures.

Psychological measurements: Everyone has a different psychological expression and various ways of thinking and responding to stressful factors, so psychological observations can help measure stress. 
Physiological measurements: In any situation when someone is faced with difficulties that may cause stress, an important hormonal reacting system to stress, the hypothalamic-pituitary adrenal (HPA) axis is activated. When the Hypothalamus, Pituitary, Adrenal glands are stimulated, they produce the hormones of Cortisol and Catecholamines. People who experience stress will account for a high proportion of these hormones in the blood, urine and plasma.

Autonomic measures: Alterations in the body's different constants and enzyme concentration can show stress. Firstly, blood pressure increases above the average level when people encounter stressful situations. Secondly, salivary alpha-amylase is also one of the main indicators for determining stress. The last is salivary Cortisol. Based on this concentration one can determine a person's stress, because it may go through the barrier of bloodbrain and change higher-level cognitive functions like memory and handling emotion (Panigrahi, 2017).

\section{Signs and Symptoms of Workplace Stress}

As emphasized by one Vietnamese manager who was interviewed, stress affects not only the individual's body and thoughts, but it also affects the emotions and ways of behaviors about things and phenomena around that person. Symptoms of stress may occur differently because it depends on the psychological and health status of each person. Overstress can cause many serious conditions, either for employees or companies. Managers and HR professionals must learn how to recognize the stressful reactions of their employees.

According to Gwilt (2014), there are 10 signs of stress during change:

1. Absenteeism and arriving late to work.

2. Work attitude becomes careless and sloppy.

3. Starts to talk negatively about the job and the company.

4. Demonstrates a resistance to change.

5. Often the ringleader of a "rumour mill" with talk about lack of trust.

6. Starts to focus on unnecessary detail.

7. Less cooperative and more hostile with management and colleagues.

8. Difficulty in concentrating and becomes more restless.

9. Complains of feeling unwell or having to deal with aches and pains.

10.Seems to be tense, uptight or nervous and talks about having trouble sleeping.

Moreover, the study of Segal, Smith, Segal and Robinson (2019) showed common warning signs and symptoms of stress overload which are presented in Table 2.

Table 2. Common warning signs and symptoms of stress overload

\begin{tabular}{|l|l|}
\hline \multicolumn{1}{|c|}{ Cognitive Symptoms } & \multicolumn{1}{c|}{ Emotional Symptoms } \\
\hline$>$ Memory problems & $>$ Depression or general unhappiness \\
$>$ Inability to concentrate & $>$ Anxiety and agitation \\
$>$ Poor judgment & $>$ Moodiness, irritability, or anger \\
$>$ Seeing only the negative & $>$ Feeling overwhelmed \\
$>$ Anxious or racing thoughts & $>$ Loneliness and isolation \\
$>$ Constant worrying & $>$ Other mental or emotional health problems \\
\hline \multicolumn{1}{|c|}{ Bhysical Symptoms } & \\
\hline Aches and pains Symptoms \\
$>$ Diarrhea or constipation & $>$ Eating more or less \\
$>$ Nausea, dizziness & $>$ Sleeping too much or too little \\
$>$ Chest pain, rapid heart rate & $>$ Withdrawing from others \\
$>$ Loss of sex drive & $>$ Procrastinating or neglecting responsibilities \\
$>$ Frequent colds or flu & $>$ Using alcohol, cigarettes, or drugs to relax \\
\hline
\end{tabular}

Source: Segal, Smith, Segal and Robinson, 2019

Besides, as reported by The American Institute of Stress (2020), stress is identified by frequent headaches, excessive worry, constant tiredness, guilt, and nervousness. It also increases depression, frustration, irritability, anger, insomnia, frustration, and nightmares. Stress can also make people forgetful while having difficulty concentrating and making decisions. People who are stressed often feel overwhelmed, lonely, or worthless, pay 
little attention to appearance, overreact to minor annoyances, and have excessive defense or doubt and serious issues in communication. Moreover, the managers who were interviewed in the present study reported that stress leads to a decrease in productivity and work efficiency, as well as an increase in utilizing tobacco, alcohol, and drugs. Additionally, stress can influence the entire body through some symptoms, both psychological and physical and make daily activities more difficult. Different stress levels cause different symptoms between each person. Apart from the usual symptoms, trouble sleeping, digestive issues, variations in appetite, loss of control in awareness, and frequent illnesses are also seen as manifestations of stress (Kandola, 2018).

Furthermore, stress is described through some other signs such as escaping from the responsibilities of work, taking unusual actions like coming late and leaving early, degrading performance and easily making errors on the job, having a low concentration at work, easily forgetting everything, being irritable from external influences, overreacting to every situation despite the big or small, impairing health, and having improper eating habits (Shukla \& Garg, 2013).

\section{Effects of Workplace Stress}

When things become too much to handle, employees generally display signs and symptoms that indicate they are feeling "stressed out" (Bickford, 2005). Unfortunately, sometimes managers may not recognize these signs and let them go untreated. Some studies have shown that untreated distress (overstress) has many negative effects on the human body system and can cause structural changes in different parts of the brain (Lupien et al., 2009).

Individual effects. Firstly, stress affects the body. It can trigger headaches and create excessive stomach acid that results in heartburn. People breathe rapidly when they are stressed due to muscle tension. Stress is one of the main causes of cardiovascular disease. Stress hormones make the heart beats faster so that blood can go quickly to important organs and an increase in heartbeat and high blood pressure over time injures the arteries that can lead to a risk of heart disease. Also, stress can impact one's sex drive and bring about fertility issues.

The body's digestive system may also be affected by stress, so it can create many illnesses like stomachache, nausea, and stomach upset. Stress is also considered as a cause of obesity and diabetes because of increased blood sugar. Long-term stress can lessen defenses in the body's immune system, so it makes the body more susceptible to infections. Moreover, stress also causes sleep disturbances, increases depression and can cause a mental breakdown (The American Institute of Stress, 2020).

Secondly, stress impacts one's mood. Some characteristics in the mood to identify someone who is stressed are anxiety, restlessness, lack of motivation or focus, feeling overwhelmed, irritability or anger, and sadness or depression (Mayo Clinic, 2019).

Thirdly, stress influences behavior. A person who is stressed usually has some behaviors like overeating or under eating, angry outbursts, drug or alcohol misuse, tobacco use, and social withdrawal (Mayo Clinic, 2019).

Besides, according to the World Health Organization (2005), one consequence of long-term exposure to stress may be burnout. Burnout is a complicated physical, mental, and emotional reaction to unceasing levels of high tension. It produces feelings of hopelessness, powerlessness, cynicism, resentment, failure, and stagnation, as well as decreases in productivity (Bickford, 2005: 13). These stress-related reactions can result in depression, which can directly threaten employees' health and indirectly impact the company. As such, it is recommended that each "stressed" individual must first change his or her thinking before he or she can feel better and fully equipped to effectively manage stress physically and mentally.

Organizational effects. When tensions occur with employees, it also affects the organization. For instance, working performance decreases and revenues decline. Stress can lead to an increase in employee turnover. Additionally, there will be the frequent absence of stressed employees and reduced satisfaction at work (Quick \& Quick, 1984).

Financial effects. As mentioned by Vietnamese managers, stressed-out employees often have low morale, are demotivated, and some ignore their important tasks and customers. As such, we can conclude that stress has negative impacts on employers and businesses directly through increased absenteeism, reduced production, increased costs, and reduced profits, and indirectly through factors such as reduced morale of staff (World Health 
Organization, 2005). The Sainsbury Centre for Mental Health (2007) indicates that the cost to British employers of stress amounts to $£ 1,035$ per employee per year. Of this total, £335 (32.4\%) is due to absenteeism, $£ 605$, or $58.4 \%$ to "presentism", and $£ 95$ to staff turnover $(9.2 \%)$.

It has been estimated that job-related stress has negative impacts on at least 40 million workers in 15 countries of the European Union, costing 20 billion euros per year (European Agency for Safety and Health at Work, 2014). This research revealed that $45 \%$ of workers had monotonous tasks; $44 \%$ did not rotate tasks; $50 \%$ had short, repetitive tasks; $35 \%$ had no impact on task order; $28 \%$ had no impact on work rhythm; $54 \%$ reported to work at very high speed, and $56 \%$ completed the work with tight deadlines.

Furthermore, a U.S. study estimate placed the cost of stress to the economy (due to absenteeism, health insurance claims, and lost productivity) at approximately $\$ 150$ billion per year (Neuman, 2004). Modern employers now are starting to realize that workplace stress is creating physical and mental health problems in their employees, which is in turn affecting the bottom line of the business (Bickford, 2005).

\section{Challenges faced by Human Resources}

According to Greeshma, Priya, Aswathy and Janani (2018), when it comes to stress management issues and opportunities, there are at least four main challenges that are faced by human resource professionals.

Identify the cause of tension: Human resource managers need to understand entirely the value of their staff, and which factors are negatively impacting the job. Besides that, human resources also need to determine exactly the causes of stress, what difficulties the employee is experiencing, and why those problems have happened with that employee. Some stressful situations occur due to work pressure or conflicts between colleagues or between employers and employees.

How to cope with strain: Stress has serious effects on both the mind and body. Therefore, when stress occurs, it should be handled cautiously; otherwise, it can result in major depression and even prevent employees from returning to work. Human resource managers must always remain calm when dealing with stress. Human resources ought to know that employees who often have a happy and stress-free life will be one of the organization's valuable resources because they will focus on doing the job and bring great productivity. Before giving solutions to handle stress, human resources should find out the root cause of the problem carefully, since it can have greater consequences and even cause the involvement of unions if employers solve the problem in inappropriate ways. The biggest challenge a human resource professional might have is the likelihood of having to deal with the psychology of the human mind in the workspace.

$>$ Solve conflict: When conflicts occur, human resource professionals should clearly understand the cause of the incident. After that, the human resources departments must analyze problems from many aspects and take the valid and right actions to entirely resolve the problem so that similar issues do not happen again. A good human resource professional always has a mind to solve issues instead of making a run of them. Changing the way, one thinks about a conflict or stress must precede its resolution and management.

$>$ Consideration: Human resource professionals should consider all suggestions and recommendations of the employer when the issue appears. If the problem only occurs between two individuals, the human resource professional is responsible for communicating with them, discussing these issues and proposing solutions.

Conversely, if the issue relates to the management of the company and all team members are facing stress, human resource department leaders should hold a meeting to exchange views on the employees' common concerns, and then human resource managers must consider and analyze approaches being suggested to solve the difficulty to make employees see the company's interest in their problems. Besides, it also helps them feel less stressed, happy and more comfortable at work (Greeshma et al., 2018).

\section{Recommendations}

There is no denying that stress existence is one of the key problems of modern work life. It is important to define coping mechanisms so that the long-term negative effects of persistent stress can be avoided. Manjlekar (2019) and Lampech (2017) gave some recommendations for effectively dealing with stress at the workplace, which include the following: 
1. Encourage employees to self-diagnose the reasons leading to stress.

2. Identify the change in individuals and open conversations regarding the work-life balance and workflow efficiency.

3. Encourage individuals to approve of stressful cases as a part of self-awareness to easily take remedial measures (Manjlekar, 2019).

4. Perform wellness programs.

5. Offer a good work environment and, to the extent possible, offer flexible work schedules.

6. Furnish health and safety measures.

7. Strengthen the inter-personal relationships at work (Lampech, 2017).

Restructuring policies, work teams and workloads, along with encouraging workers to take vacations for their holidays and offering stress reduction training and a variety of support services for employees, can be essential approaches to decrease stress (Tyler, 2006). The specific strategies adopted will depend on the needs of the organization and its employees and the resources available.

\section{Stress management strategies}

For individual. Employees should make a daily work schedule and organize their tasks in order of priority for first doing the important things to minimize stressors. Employees should also have effective time management by combining hard work and regular rest to help reduce work pressures and achieve their goals. Employees should have an appropriate diet, participate in physical exercises, and always have positive thoughts about their jobs. Moreover, they must also always have self-awareness, and self-control at work and build social support to assist overcome tensions (Shukla \& Garg, 2013).

Research that was conducted by Panigrahi (2017) showed some effective methods to combat stress. For example, employees should get more sleep, promote relaxation techniques such as yoga, arts, dance, music, and avoid habits such as smoking and excessive alcohol usage, and learn approaches and skills to cope with stress. Delegation of responsibility and not over-committing are two suggestions that Jain and Batra (2015) mentioned in their research paper. Employees who disapprove of blame and unnecessary criticism, abandon the distractions and habits of the complaint, actively participate in social activities, and reduce the use of caffeine and sugar can raise their resistance to stress (Prasad, Vaidya \& Kumar, 2016).

For organization. Most managers interviewed in this study agree on the importance of "encouraging employees' participation in giving their opinions and making decisions", "setting realistic goals and fairness in both incentive policy and salary system", as well as "valuing their achievements that exceed the job requirements", to reduce workplace stress. Additionally, managers should encourage more friendly and effective communication between employees to avoid conflicts within the company and role ambiguity (Shukla \& Garg, 2013).

Furthermore, as agreed upon by managers interviewed for this study, supporting employees to create positive relationships between peers, spending time relaxing with family each day, decreasing conflicts with others on the job, arranging a time to walk around the office while working to keep your body refreshed and uplift the spirit, providing more control at work for employees, allowing employees to participate in activities organized in the company, and adjusting flexible working time are some of the helpful recommendations for employees to reduce stress at work (Prasad, Vaidya \& Kumar, 2016).

Overall, there are some specific primary, secondary and tertiary approaches to reducing stress in the modern workplace as recommended by Holman, Johnson and O'Connor (2018) in their recent publication (see Table 3). 
Table 3. Three approaches to reducing workplace stress

\begin{tabular}{|c|c|c|c|}
\hline $\begin{array}{c}\text { Intervention } \\
\text { type }\end{array}$ & Goal & Individual & Organisational \\
\hline Primary & $\begin{array}{l}\text { Prevent tension from } \\
\text { happening in employee }\end{array}$ & $\begin{array}{l}>\text { Selection and assessment } \\
>\text { Pre-employment medical examination }\end{array}$ & $\begin{array}{l}>\text { Job Redesign } \\
>\text { Working time and schedules } \\
>\text { Management training, e.g. mentoring }\end{array}$ \\
\hline Secondary & $\begin{array}{l}\text { Find ways to equip } \\
\text { employees with the } \\
\text { knowledge and skills to } \\
\text { manage stressful } \\
\text { conditions } \\
\text { Give opportunities for } \\
\text { employees to engage in } \\
\text { activities to lessen stress }\end{array}$ & $\begin{array}{l}>\text { Mindfulness training } \\
>\text { Health promotion, e.g., exercise } \\
>\text { Cognitive-behavioural therapy } \\
>\text { Melaxation } \\
>\text { Personal and interpersonal skill } \\
\text { training } \\
>\text { Acceptance and commitment therapy } \\
>\text { Psychosocial intervention training } \\
>\text { Coping skills training } \\
>\text { Resilience training }\end{array}$ & $\begin{array}{l}>\text { Improving communication and } \\
\text { decision making } \\
>\text { Conflict management } \\
>\text { Peer support groups } \\
>\text { Coaching and career planning }\end{array}$ \\
\hline Tertiary & $\begin{array}{l}\text { Concentrate on the } \\
\text { employee with a high } \\
\text { stress level that can } \\
\text { impair the ability to } \\
\text { perform their work }\end{array}$ & $\begin{array}{l}>\text { Employee Assistance Programs } \\
>\text { Counselling } \\
>\text { Posttraumatic stress assistance } \\
>\text { Disability management }\end{array}$ & $\begin{array}{l}>\text { Vocational rehabilitation } \\
>\text { Outplacement }\end{array}$ \\
\hline
\end{tabular}

Source: Holman, Johnson and O'Connor, 2018

\section{The Role of HR in Managing Stress at workplace}

As a manager, it is important to understand that employees' mental health is a vital tool for successfully running a department while increasing productivity and profits. Treating mental and physical stresses early not only benefits the employees themselves, but it can also save companies a great deal of money and lost productivity.

The World Health Organization (2007) recommended certain suggestions for the prevention of work-related stress that managers can apply; see Figure 2 which presents the five action-oriented steps.

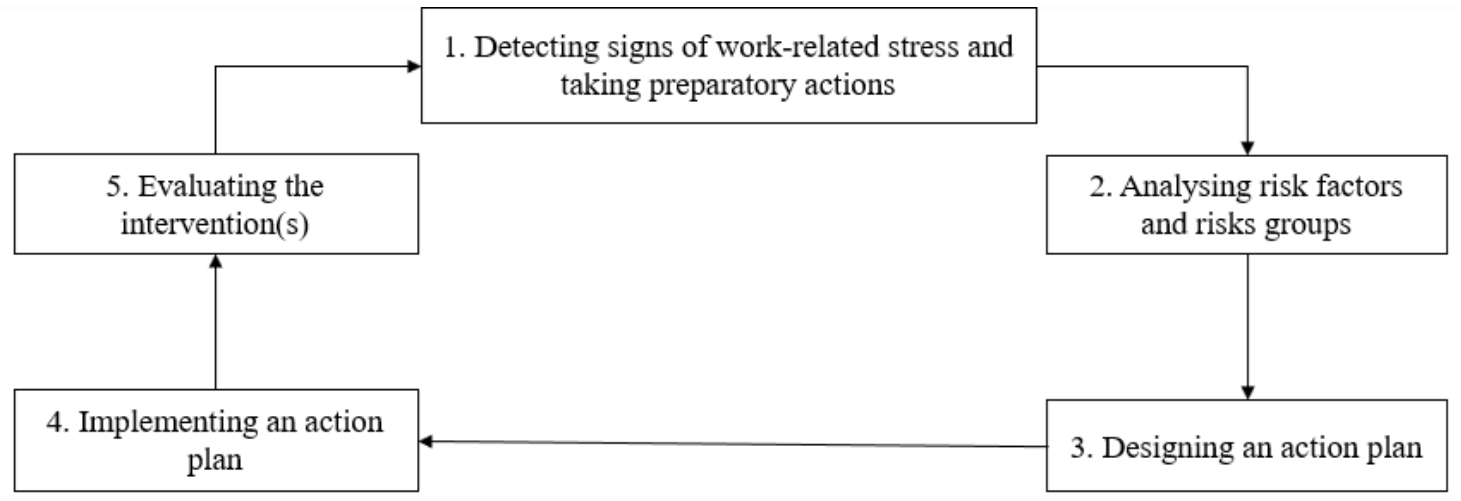

Source: World Health Organization, 2007

Figure 2. Process of Stress Prevention

There are some important roles and responsibilities that an HR manager needs to do in stress management (Balaji, 2014):

1. Identify types of stress in the workplace.

2. Understand the reasons which lead to stress at the workplace.

3. Ask employees: What solutions can be taken to prevent these stresses?

4. Build policies about stress management appropriately and effectively to handle stress in the company.

5. Discuss and engage with the staff about the problems of stress, enhance their awareness in the method of working or other related aspects.

6. Perform management standards well to determine the level of stress, and what approaches might be applied to solve the current circumstance.

7. Discuss with other departments in building and applying the resolutions. 
8. Observe and adjust stress management methods following company policies and procedures.

9. Coordinate with managers to promptly detect and help employees who are under stress.

10.Establish sustainable policies that can improve employees' welfare and health.

Throughout the process of planning and implementing the stress-reducing policies, HR managers need to clarify, explain and provide guidance for managers from other departments to ensure the intended results. Out of five Vietnamese leaders and managers participating in the in-depth interviews conducted for this study, four emphasized the crucial role of HR managers in maintaining a balanced interactive framework for systematic stress elimination. Besides, HR managers play a key role in supervising the effectiveness of methods to resolve tensions, providing training on identifying and managing stress for employees through development programs for managers and leaders, as well as giving continuous support to managers and employees in a changing environment, and counselling services to staff when necessary (Smith, 2014).

\section{Implications}

There are some important implications of the research. First, the study gives evidence of realities and specific causes that can lead to workplace stress. The purpose of clearly stating the cause is to help employees understand the reasons of stress for them and help the organization understand why employees are often stressed.

Secondly, the study provides some signs, symptoms and effects of stress on the job with the desire to improve understanding of employees on stress issues. Organizations need to promptly identify individuals who are overly stressed at work and help them make appropriate adjustments to reduce it.

Next, apart from identifying the causes and effects of stress, the study also provided helpful solutions to assist employees to balance their work and life, reduce undue pressure, escape from workplace stress, and increase productivity and quality of work. Finally, the study also pointed out the role of human resource professionals in managing stress at the modern workplace. The study provides evidence that a human resource department plays an important role in resolving personnel issues, including stress at work between employees or between employees and the organization. Therefore, human resource departments need to have appropriate strategies and policies to immediately overcome stressful situations to assist individuals to return to a happy life and work effectively to keep the company running successfully.

\section{Conclusion}

From this paper, we can summarize that stress is one of the anxieties of any employee in the modern workplace. If stress exceeds a certain level, it will cause serious consequences to the body, mood and behavior of employees. This paper gave readers detailed information about issues of workplace stress, including the causes, symptoms and consequences of individual, organization and finance. The research also shows a strong relationship between tensions on the job and influences on the health of staff. Stress could not be completely avoided and can occur at any time. When employees create too much pressure at work by setting many goals beyond their abilities, stress can lead to dangerous effects on themselves and the organization. Hence, the research provided some recommendations and highlights the role of human resources in settling workplace stresses.

\section{References}

1. Ahmad, A., Hussain, A., Saleem, M. Q., \& Qureshi, M. A. M. (2015). Workplace Stress: A Critical Insight of Causes, Effects and Interventions. Technical Journal, University of Engineering and Technology (UET) Taxila, Pakistan, 20(II), 46, 48. Retrieved from: https://www.semanticscholar.org/paper/Workplace-Stress\%3A-A-Critical-Insight-of-Causes-\%2C-Ahmad-Hussain/4552df3dc0a937dae2f2aa5e28d30561bae60e88.

2. Ahmed, S.K., Khan, M.M., Khan, R.A., \& Mujtaba, B.G. (March 2020). The Relationship between Social Capital and Psychological Well-Being: the Mediating Role of Internet Marketing. Marketing and Management of Innovations, 1, 40-53. http://doi.org/10.21272/mmi.2020.1-03.

3. Bickford, M. (2005). Stress in the Workplace: A General Overview of the Causes, the Effects, and the Solutions. Canadian Mental Health Association, 9-10, 11-15, Link: https://myfreedom2017.com/wpcontent/uploads/2017/04/Work-Place-Stress.pdf. 
4. Beehr, T. A., \& Newman, J. E. (1978). Job stress, employee health, and organizational effectiveness: a facet analysis, model, and literature review. Personnel Psychology, 31, 671-674. Link: http://dx.doi.org/10.1111/j.1744-6570.1978.tb02118.x.

5. Balaji, R. (2014). Role of Human Resource Manager in Managing Stress of Employees in Manufacturing Concerns. International Journal of Innovative Research in Science, Engineering and Technology, 3(4), 11070-11071. Retrieved from: https://www.researchgate.net/publication/321126407_Role_of_Human_Resource_Manager_in_Managing_S tress_of_Employees_in_Manufacturing_Concerns.

6. Cleveland Clinic. (2015). Stress. Retrieved from: https://my.clevelandclinic.org/health/articles/11874-stress.

7. Canadian Mental Health Association. (2016). Stress. Retrieved from: https://cmha.ca/documents/stress.

8. Hassard, J., Teoh, K., Cox, T., Dewe, P., Cosmar, M., Grundler, R., \& Van den Broek, K. (2014). Calculating the costs of work-related stress and psychosocial risks - a literature review European agency for safety and health at work (EU-OSHA). Luxembourg. DOI:10.2802/20493. Retrieved from: https://osha.europa.eu/en/publications/literature_reviews/calculating-the-cost-of-work-related-stress-andpsychosocial-risks.

9. Greeshma, B., Priya, G. I., Aswathy, B., \& Janani, S. (2018). Stress Management in the Workplace- Challenges Faced By HR. Journal of Business and Management, 20(4), 33-36. Retrieved from: http://www.iosrjournals.org/iosr-jbm/papers/Vol20-issue4/Version-3/F2004033336.pdf.

10.Grimshaw, J. (1999). Employment and health: Psychosocial stress in the workplace. London: The British Library, $2 . \quad$ Retrieved from: https://www.researchgate.net/publication/280191013_Employment_and_Health2000132Jennie_Grimshaw_ Employment_and_Health_Psychosocial_Stress_in_the_Workplace_London_The_British_Library_1999_418 _pp_ISBN_0_7123_0847_4_3800.

11. Gwilt, B. (2014). Top 10 signs of stress during change. CDL Insight Consulting. Retrieved from: https://www.cdlinsight.co.nz/top-10-signs-of-stress-during-change/.

12. Health and Safety Executive, (2020). What are the Management Standards? Retrieved from: https://www.hse.gov.uk/stress/standards/.

13. Holman, D., Johnson, S., \& O'Connor, E. (2018). Stress management interventions: Improving subjective psychological well-being in the workplace. In E. Diener, S. Oishi, \& L. Tay (Eds.), Handbook of well-being. Salt Lake City, UT: DEF Publishers. 2. Retrieved from: https://nobascholar.com/chapters/44/download.pdf.

14. Ibrahim, A.R., Imtiaz, G., Mujtaba, B.G., Vo, X.V. \& Ahmed, Z.U. (2020). Operational Excellence through Lean Manufacturing: Considerations for Productivity Management in Malaysia's Construction Industry. Journal of Transnational Management, 25(3), 1-32. DOI: 10.1080/15475778.2020.1749809.

15. Jain, P. \& Batra, A. (2015). Occupational Stress at Workplace: Study of the Corporate Sector in India. Journal of Business and Management, 17(1), 13-21. Retrieved from: http://www.iosrjournals.org/iosrjbm/papers/Vol17-issue1/Version-3/B017131321.pdf.

16. Kazmi, S. S. H. (2019). Traumashastra: Biopsychosocial Perspectives of Trauma. Indian Mental Health and Research Centre, May 6, 2019, 58. Retrieved from: https://www.academia.edu/41510983/Traumashastra_Biopsychosocial_Perspectives_of_Trauma.

17. Kandola, A. (2018). What are the health effects of chronic stress? Retrieved from: https://www.medicalnewstoday.com/articles/323324.

18. Kendall, E., Murphy, P., O’Neill, V., \& Bursnall, S. (2000). Occupational stress: factors that contribute to its occurrence and effective management, Government of Western Australia, 5-6. Retrieved from: http://www.mentalhealthpromotion.net/resources/occupational-stress-fractors-that-contribute-to-itsoccurrence-and-effective-management.pdf.

19. Lazarus, R. S. (1991). Psychological stress in the workplace. In P.L. Perrewe (Ed.), Handbook on Job Stress. Corte Madera, CA: Select Press, 1-13. Retrieved https://www.researchgate.net/publication/20491179_Psychological_Stress_in_the_Workplace.

20. Lupien, S. J., McEwen, B. S., Gunnar, M. R., \& Heim, C. (2009). Effects of stress throughout the lifespan on the brain, behaviour and cognition. Nat Rev Neurosci, 434-445. DOI: 10.1038/nrn2639. 
Business Ethics and Leadership, Volume 4, Issue 2, 2020

ISSN (online) - 2520-6311; ISSN (print) - 2520-6761

21. Lampech, W. (2017). HR Strategies to Manage Stress in the Workplace. Retrieved from: https://theundercoverrecruiter.com/strategies-to-manage-stress/.

22. Martin, D. (2018). Effects of Stress: The Link between Pressure and Performance. Delphis. https://delphis.org.uk/peak-performance/effects-of-stress-the-link-between-pressure-and-performance/.

23. Manoj, A. S. (2013). An Analytical Study on Employee Stress with Special Reference to Information Technology (It) Companies in Technopark - A Kerala Experience. International Journal of Advanced Research in Management and Social Sciences, 2(11), 156-157. Retrieved from: http://www.garph.co.uk/IJARMSS/Nov2013/15.pdf.

24. Michie, S. (2002). Causes and Management of Stress at Work. Occupational and Environmental Medicine, 59(1), 67-72. Retrieved from: http://dx.doi.org/10.1136/oem.59.1.67.

25. Malik, N. (2011). A study on occupational stress experienced by private and public banks employees in Quetta City. African Journal of Business Management, 5(8), 3063-3070. DOI: 10.5897/AJBM10.199.

26. Mayo Clinic. (2019). Stress symptoms: Effects on your body and behavior. Retrieved from: https://www.mayoclinic.org/healthy-lifestyle/stress-management/in-depth/stress-symptoms/art-20050987.

27. Manjlekar, J. (2019). Here's what HR must do to reduce workplace stress. Retrieved from: https://www.indiatoday.in/education-today/jobs-and-careers/story/here-s-what-hr-must-do-to-reduce-stressin-the-workplace-1442467-2019-01-30.

28. Mujtaba, B. G., Cavico, F. J., and Senathip, T. (2020). Strategies for Personal, Organizational and Professional Leadership Success. Scientific Journal of Research \& Reviews, 2(3), 1-10. DOI:10.33552/SJRR.2020.02.000538.

29. Mujtaba, B. G. and McCartney, T. (2010). Managing Workplace Stress and Conflict amid Change, $2^{\text {nd }}$ edition. ILEAD Academy; Florida. Retrieved from: http://works.bepress.com/bahaudin-mujtaba/245/.

30. Neuman, J. H. (2004). Chapter 3: Injustice, stress, and aggression in organizations. In R. W. Griffen \& A. M. O'Leary-Kelly (Eds.), The dark side of organizational behavior. San Francisco, CA: Jossey-Bass, 74. Retrieved from: https://www.researchgate.net/publication/291169363_The_Dark_Side_of_Organizational_Behavior.

31. Nguyen, L. D., Lee, K-H., Mujtaba, B. G., and Ruijs, A. (2013). Cross-culture management: An examination on task, relationship and stress orientations of Dutch and Vietnamese. International Journal of Asian Business and Information Management, 4(4), 1-21. Retrieved from: https://ideas.repec.org/a/igg/jabim0/v4y2013i4p1 21.html.

32. Nguyen, L.D., Mujtaba, B. G., \& Pham, L.N.T. (2013). Cross-culture management: An examination on task, relationship and stress orientations of Japanese and Vietnamese. International Journal of Strategic Change Management, 5(1), 72-92. Retrieved from: https://www.researchgate.net/publication/264812439_Crossculture_management_an_examination_on_task_relationship_and_work_overload_stress_orientations_of_Ja panese_and_Vietnamese.

33. Nordqvist, C. (2017). Why stress happens and how to manage it. Medical News Today. Retrieved from: https://www.medicalnewstoday.com/articles/145855.

34. Parasuraman, S., \& Alutto, J. A. (1984). Sources and Outcomes of Stress in Organizational Settings: Toward the Development of a Structural Model. The Academy of Management Journal, 27(2), 330-350. Retrieved from: https://www.jstor.org/stable/255928?seq=1.

35. Panigrahi, A. (2017). Managing stress at workplace. Journal of Management Research and Analysis, 3(4), 154-160. DOI: 10.18231/2394-2770.2016.0001.

36. Prasad, K. D. V., Vaidya, R., \& Kumar, V. A. (2016). Study on The Causes of Stress Among the Employees in It Sector and Its Effect on The Employee Performance At The Workplace With Special Reference To International Agricultural Research Institute, Hyderabad: A Comparative Analysis. International Journal of Management, 7(4), 76-98. Retrieved from: http://www.iaeme.com/ijm/issues.asp?JType=IJM\&VType=7\&IType=4.

37. Quick, J. C., \& Quick, J. D. (1984). Organizational stress and preventive management, 19, 44, 76. New York: McGraw-Hill.

Retrieved

from:

https://www.researchgate.net/publication/275761837_Occupational_Stress_and_Preventive_Management.

38. Sainsbury Centre for Mental Health. (2007). Mental health at work: developing a business case, policy. Retrieved from: http://www.centreformentalhealth.org.uk/pdfs/mental_health_at_work.pdf.

39. Segal, J., Smith, M., Segal, R., \& Robinson, L. (2019). Stress Symptoms, Signs, and Causes. HelpGuideorg International. Retrieved from: https://www.helpguide.org/articles/stress/stress-symptoms-signs-andcauses.htm. 
40. Selye, H. (1936). A Syndrome Produced by Diverse Nocuous Agents. NatureSearch, 32, 138. DOI: 10.1038/138032a0.

41. Semmer, N. K. (2007). Stress at the workplace. World Health Organization. Retrieved from: https://www.who.int/occupational_health/topics/stressatwp/en/.

42. Semmer, N. K., Jacobshagen, N., Meier, L. L., Elfering, A., Beehr, T. A., Kälin, W., \& Tschan, F. (2014). Illegitimate tasks as a source of work stress. Work \& Stress, 29(1), 32-56. Retrieved from: http://dx.doi.org/10.1080/02678373.2014.1003996.

43. Seňová, A. \& Antošová, M. (2014). Work stress as a worldwide problem in present time, 2nd World Conference on Business, Economics and Management-WCBEM2013, Procedia - Social and Behavioral Sciences 109 (2014), 312-313. Retrieved from: https://www.sciencedirect.com/science/article/pii/S1877042813050957\#aep-articlefootnote-id3.

44. Shoaib, S., Mujtaba, B.G. \& Awan, H.M. (September 2019). Overload Stress Perceptions of Public Sector Employees in Pakistan: A Study of Gender, Age, and Education in South Asia. Public Organization Review, 19(3), 331-324. DOI: https://doi.org/10.1007/s11115-018-0405-y.

45. Shukla, H., \& Garg, R. (2013). A Study on Stress Management among the Employees of Nationalised Banks. Voice of Research, 2(3), 72-73. Retrieved from: http://www.voiceofresearch.org/Doc/Dec-2013/Dec2013_20.pdf.

46. Smith, P. (2014). Procedure for Managing Stress in the Workplace. NHS Rotherham Clinical Commissioning Group, 3-5. Retrieved from: http://www.rotherhamccg.nhs.uk/Downloads/Policies\%20and\%20Procedures/HR\%20Policy/029HR\%20Procedure\%20For\%20Managing\%20Stress\%20In\%20The\%20Workplace.pdf.

47. Stress Management. (2020). Psychologist World. Retrieved from: https://www.psychologistworld.com/stress/stress-management.

48. The American Institute of Stress. (2020). 50 Common Signs and Symptoms of Stress. Retrieved from: https://www.stress.org/stress-effects.

49. The American Institute of Stress. (2020). How Stress Affects Your Body. Retrieved from: https://www.stress.org/how-stress-affects-your-body.

50. Tyler, K. (2006). Stress Management. Retrieved from: https://www.shrm.org/hr-today/news/hrmagazine/pages/0906tyler.aspx.

51. Tucker, Michelle K., Jimmieson, Nerina L., Tian P. (2013). The relevance of shared experiences: A multilevel study of collective efficacy as a moderator of job control in the stressor-strain relationship. Work \& Stress, 27(1), 21. DOI: 10.1080/02678373.2013.772356.

52. Vanishree, P. (2014). Impact of Role Ambiguity, Role Conflict and Role Overload on Job Stress in Small and Medium Scale Industries. Research Journal of Management Sciences, 3(1), 10-13. Retrieved from: https://www.semanticscholar.org/paper/Impact-of-Role-Ambiguity\%2C-Role-Conflict-and-Role-onVanishree/2f3f37fdb4afa88dc84e0210768d4fc30e8f631f.

53. World Health Organization (2007). Raising awareness of stress at work in developing countries. Protecting Workers' Health Series, 6. Printed in France, 17, 23. Retrieved from: https://www.who.int/occupational_health/publications/raisingawarenessofstress.pdf?ua=1 .

54. World Health Organization, (2005). Mental health policies and programs in the workplace. Mental health policy and service guidance package, 18, 20. Retrieved from:

https://apps.who.int/iris/bitstream/handle/10665/43337/9241546794_eng.pdf. 